\title{
Pemberitaan Isu Terorisme Pada Media di Indonesia: Media Kompas.com dan Voa-Islam.com dalam Peristiwa Serangan Paris November 2015
}

\author{
Renita Novitasari Putri ${ }^{1}$, Zarmansyah $^{2}$ \\ ${ }^{1,2}$ Institut Komunikasi dan Bisnis LSPR, Jakarta, Indonesia
}

\begin{abstract}
ABSTRAK
Terorisme merupakan suatu isu yang berkembang sejak lama dan saat ini menjadi hal yang dikhawatirkan masyarakat dunia. Anggapan tersebut muncul setelah apa yang diberitakan oleh media dapat membentuk suatu persepsi/opini publik. Besarnya pengaruh media kepada masyarakat didukung pula oleh perkembangan teknologi pada media yang saat ini kian memunculkan kecepatan dan keaktualitasannya melalui media online. Media online di Indonesia sendiri bermacam-macam, seperti Kompas.com dan VOA-islam.com yang memiliki latar belakang yang berbeda. Dengan menggunakan metode kualitatif yaitu wawancara, analisis framing dalam teori agenda setting dan opini publik sebagai pendukung, penelitian ini menunjukkan bahwa kedua media memberitakan dengan sudut pandang dan cara yang berbeda dalam peristiwa serangan Paris November 2015. Dari serangkaian hasil wawancara dan analisis, penelitian ini menghasilkan suatu pembuktian bahwa setiap media akan memberitakan suatu peristiwa menurut ideologi dan visi-misi masing-masing tergantung dari editor/redaktur media tersebut, termasuk dalam pemilihan referensi dan media asing sebagai media pembanding.
\end{abstract}

Kata kunci: Serangan Paris, pemberitaan, terorisme, media, online

\section{Reporting on Terrorism Issues in the Media in Indonesia: Media Kompas.com and Voa-Islam.com in the Paris Attack Incident November 2015}

\begin{abstract}
Terrorism is an issue that has grown for a long time and is now a concern to the world community. This comes after what is being reported by the media can form a public perception or opinion. The amount of media influence on the public is supported also by technological developments in the media that currently raise the speed of delivery and its actuality through online media. Online media in Indonesia itself has many kinds, such as Kompas.com and VOA-islam.com which have two different backgrounds. Using the qualitative method of interviewing, framing analysis in agenda setting theory and public opinion as supporting theory, this research shows that both media were covering the Paris attacks in November with different methods and points of view. This research has proof that every media will cover an event according to the ideology and characteristic (mission and vision) respectively depending on the editor of the media, including in the selection of referrals and foreign media as a comparison
\end{abstract}

Keywords: Paris attack, terrorism, news, online, media 


\section{PENDAHULUAN}

Terorisme merupakan suatu transnational threat berupa ancaman serangan dan memiliki suatu tujuan tertentu yang telah berkembang sejak lama dan kini menjadi hal yang mengkhawatirkan bagi masyarakat internasional semenjak munculnya kelompok-kelompok militan yang menyerang beberapa Negara di Eropa, Asia, dan Timur Tengah. Terorisme internasional dianggap menjadi suatu hal yang menjadi momok dan hal yang harus dilawan oleh dunia. Hal ini terbukti pada pernyataan Presiden Amerika Serikat, Barrack Obama saat berbicara tentang penganggulangan terorisme dalam Gedung Putih yang dilansir Reuters, dan juga pernyataan PM Inggris, David Cameron.

Obama mengatakan "Saya ingin Anda tahu, ancaman terorisme itu nyata tetapi kita akan mengakhirinya. Kita akan menghancurkan ISIS dan organisasi lain yang membahayakan kita, Militer kita akan terus memburu komplotan teroris di negara manapun jika diperlukan" (Ratomo, 2015). Pernyataan yang diliput oleh media tersebut menegaskan bahwa Obama akan berupaya mengakhiri terorisme, menghancurkan ISIS dan juga organisasi semacamnya. Hal tersebut dikatakannya pasca dunia dikejutkan dengan serangan teror yang melanda Paris, ibukota Prancis yang kemudian telah diklaim oleh ISIS bahwa mereka yang bertanggung jawab akan terjadinya penyerangan tersebut (Rochmanuddin, 2015). Sebelumnya Paris pun telah diserang oleh sekelompok militan di kantor majalah Charlie Hebdo pada bulan Januari 2015.

ISIS atau Islamic State of Iraq and Syria merupakan organisasi yang mengatasnamakan Islam dan menjadi suatu organisasi yang paling diperangi belakangan ini karena aksi terornya yang memporakporandakan berbagai penjuru dunia, bahkan Indonesia. Hingga pada tanggal 13 November 2015, masyarakat Paris dihebohkan dengan terjadinya serangkaian serangan teror bom bunuh diri dan penembakan di tujuh lokasi yang pelakunya lagi-lagi adalah ISIS. Mereka mengklaim bertanggung jawab akan peristiwa tersebut melalu beberapa sosial media mereka. Setidaknya 129 orang tewas dalam peristiwa saat malam hari tersebut (Saifulloh, 2015). Setelah terjadinya peristiwa tersebut, reaksi media massa dan media sosial di seluruh dunia sangat besar. Kejadian yang merenggut nyawa yang tidak sedikit itu kemudian langsung membuat warga dunia bersimpati, termasuk ungkapan bela sungkawa dari banyak tokoh-tokoh penting dunia, dukungan untuk warga Paris juga bermunculan dengan berbagai ekspresi seperti hashtag \#PrayforParis yang didedikasikan untuk kejadian tersebut melalui berbagai media sosial seperti Twitter, Facebook, Instagram dan lain sebagainya. Peristiwa ini juga tentu menimbulkan reaksi yang berbeda-beda pada masyarakat terhadap pelaku serangan teror yaitu Islamic State of Iraq and Syria (ISIS).

Informasi kejadian tersebut pun tersebar sehingga menjadi viral bahkan menjadi suatu trending topic dunia karena masyarakat dapat dengan cepat memperoleh dan memperbaharui informasi seputar peristiwa portal berita media internasional yang berpengaruh seperti New York Times, The Sun, Le Depeche, dan sebagainya. Dengan adanya perkembangan informasi dan teknologi komunikasi, media pun telah berkembang dan memberikan nuansa baru pada pemberitaan isu teror. Media sosial dan online merupakan media yang tentu saja lebih mudah diakses 
dibandingkan dengan media konvensional. Media-media sosial dan online internasional terlebih dahulu memberitakan peristiwa Paris terserbut dan kemudian disusul dengan mediamedia nasional yang juga memberitakannya. Munculnya media online internasional seperti CNN.com, AFP.com, dan BBC.com memberikan suatu kesan yang baru, karena sebelumnya aksi teror hanya disiarkan melalui breaking news pada media konvensional seperti televisi atau radio. Kini aksi teror dapat dengan mudah disaksikan dan diketahui perkembangannya melalui media baru seperti media sosial Youtube, Twitter, Facebook maupun portal media online. Kehadiran media online ini juga dapat dengan mudah mempengaruhi persepsi dan reaksi publik karena semua orang dapat dengan mudah mengakses portal berita yang mereka inginkan kapan pun dan di mana pun (Nugroho, 2020).

Fenomena ini menarik karena di samping kemudahan masyarakat dunia untuk mengakses informasi dari segala media termasuk media sosial dan media online, media juga dapat membentuk suatu persepsi melalui berita-berita yang mereka publikasikan dari sudut pandang masing-masing korporasi. Selain itu, isu tentang terorisme internasional telah menjadi isu yang paling sering dibahas pada media massa sepanjang tahun 2015 menurut Indonesia Indicator (I2) yaitu mendominasi pemberitaan di 1.230 media online nasional dan media online internasional berbahasa Inggris (Susanti, 2015). Hal ini menunjukkan bahwa media online berpengaruh penting dalam membuat suatu anggapan tentang isu terorisme di Indonesia.

Seiring dengan berkembangnya globalisasi media, seperti yang dikatakan oleh Indonesia Indicator (I2), tidak hanya media online internasional berbahasa Inggris saja, media online di Indonesia juga sempat memberitakan tentang terorisme yang terjadi di Paris. Media online seperti Kompas.com dan VOA-Islam.com memberitakan serangan tersebut, namun kedua media ini memiliki slogan/tagline yang berbeda. Kompas.com dengan "Rayakan Perbedaan" dan VOA-Islam.com yang tadinya "Voice of The Truth" namun kini menjadi "2009-2017, 8 Tahun Kobarkan Amar Maruf Nahi Munkar". Meskipun demikian hal tersebut bukan merupakan suatu jurang bagi pertarungan untuk merebut bangsa pasar pembacanya, tetapi hal tersebut menjadi suatu pertimbangan melihat setiap media pasti memiliki visi- misi dan ideologi yang berbeda-beda. Peneliti juga akan melihat dari sisi priming dan framing kedua media untuk mencari apakah ada perbedaan yang signifikan pada kedua media dalam memberitakan isu terorisme. Oleh karena itu, penulis membuat rumusan masalah yakni: Bagaimana pemberitaan isu terorisme serangan Paris November 2015 pada media di Indonesia?

\section{Agenda Setting II}

Teori Agenda-setting menjelaskan "kemampuan (dari media berita) untuk mempengaruhi arti penting dari topik dalam agenda publik" (McCombs \& Reynolds, 2002). Artinya, jika sebuah berita dikemas secara sering dan mencolok, audience akan menganggap suatu isu sebagai isu yang lebih penting dibandingkan isu-isu yang lain. Penelitian tentang efek agenda setting adalah untuk membandingkan arti-penting isu dalam isi berita dengan persepsi publik dari isu yang paling penting, dan kemudian membuktikan apakah ada pengaruh oleh media. Ada tiga model yang diasumsikan oleh Max McCombs, antara lain: Model Kesadaran, Model Prioritas, 
Model Arti. Kebanyakan investigasi dan penelitian berpusat pada tiga model ini.

Dalam penelitian, variabel dependen adalah agenda media (Media Agenda Setting), agenda khalayak (Public Agenda Setting) dan agenda kebijakan (Public Policy Agenda Setting) seperti yang tercantum di bagian berikut, tiga jenis pengaturan agenda. Ada tiga jenis dasar agenda setting sesuai menurut Everett Rogers dan J.W. Dearing (Rogers \& Dearing, 1988, pp. 555594), antara lain:

1. Public Agenda Setting, di mana agenda publik adalah variabel dependen (hipotesis tradisional). Pengaturan agenda publik berfokus pada agenda audience.

2. Media Agenda Setting, di mana agenda media diperlakukan sebagai variabel dependen ("pembangunan agenda") Agenda Setting media berfokus pada pengaruh media massa pada audience.

3. Public Policy Agenda Setting, di mana agenda elit pembuat kebijakan diperlakukan sebagai variabel dependen ("agenda setting politik") dan berfokus pada bagaimana media dan publik dapat mempengaruhi keputusan pada elit pembuat kebijakan. (Walgrafe \& Van Aelst, 2006)

\section{Priming}

Priming menurut Severin dan Tankard, Jr., adalah "Priming adalah proses di mana media berfokus kepada sebagian isu dan tidak pada isu lainnya dan dengan demikian mengubah standar yang digunakan orang untuk mengevaluasi para calon pemilihan" (Severin \& Tankard, 2011, p. 271). Priming merupakan bagian penting dari agenda setting yang menunjukkan bahwa media menarik perhatian kepada suatu aspek tertentu daripada aspek lainnya. Penempatan suatu berita dapat memiliki efek agenda setting yang lebih besar, karena masyarakat akan cenderung melihat atau memerhatikan berita di awal, kedua, orang-orang menerima suatu rancangan implisit dari program berita, bahwa berita utama itulah yang paling penting (Tamburaka, 2012). Iyengar (1991) menyebutkan, "Sementara agenda setting menawarkan perbedaan terhadap isu nasional yang dianggap penting, priming merujuk kepada dampak pemberitaan dalam kekuatan yang diberikan kepada isu tertentu dalam membuat penilaian politik," (Davis \& Baran, 2010, p. 349).

\section{Framing}

Analisis framing atau analisis bingkai adalah suatu ilmu mendalam untuk meneliti isi teks media yang dipublikasikan kepada khalayak yang pertama kali digagas oleh Beterson pada tahun 1955. Frame pada awalnya diartikan sebagai struktur konseptual atau perangkat kepercayaan yang mengorganisasi pandangan politik, kebijakan dan wacana serta menyediakan kategori-kategori standar untuk mengapresiasi realitas (Sobur, 2006). Framing kemudian dikembangkan lagi oleh Erving Goffman, yang kemudian dikutip oleh Alex Sobur (2006) Goffman mengatakan bahwa setiap individu memiliki kemampuan untuk memaknai situasi dan orang-orang dalam kehidupan sehari-hari tanpa perlu berupaya keras untuk menciptakan pengalaman realitasnya. Pengalaman realitas dapat dikonstruksi oleh orang yang memiliki pengalaman dari realitas tersebut (Sobur, 2006). 
Robert N. Entman melihat framing dalam 2 dimensi besar, yaitu seleksi isu dan penelakan atau penonjolan aspek-aspek tertentu dari realitas suatu isu. Entman mengatakan seleksi isu dilakukan oleh individu dalam memilih topik yang dapat menarik perhatian banyak khalayak, sedangkan penonjolan aspek dilakukan untuk memusatkan perhatian khalayak terhadap aspek tersebut (Eriyanto, 2002). Dengan lebih jelasnya, framing merupakan sebuah cara bagaimana suatu isu atau peristiwa disajikan oleh media. Penyajian tersebut dilakukan dengan cara menyeleksi isu yang dianggap lebih penting dan menonjolkan aspek tertentu sehingga peristiwa tersebut lebih dapat dimengerti dan diingat oleh publik.

\section{Model Analisis Framing William A. Gamson dan Andre Modigliani}

Model framing William Gamson dan Andre Modigliani menyatakan bahwa terdapat cara bercerita atau gugusan ide-ide yang terorganisasi sedemikian rupa dan menghasilkan konstruksi makna peristiwa yang berkaitan dengan objek suatu wacana. Cara bercerita dalam berita itu terbentuk dalam suatu kemasan (package). Kemasan (package) adalah semacam skema atau struktur pemahaman yang digunakan untuk membangun makna pesan yang akan disampaikan, juga untuk menafsirkan makna pesan-pesan yang diterima (Eriyanto, 2002).

Menurut Gamson \& Modigliani, terdapat struktur internal dalam sebuah package. Pada bagian sentral merupakan konfigurasi ide, atau frame, untuk memahami suatu peristiwa dan menunjukkan apa yang menjadi isu (Gamson \& Modigliani, 1989). Konsep framing Gamson \& Modigliani banyak menekankan penandaan dalam bentuk simbolik, baik lewat kiasan maupun retorika yang secara tidak langsung megarahkan perhatian khalayak (Eriyanto, 2002). Kerangka framing Gamson \& Modigliani secara khusus berguna karena menarik perhatian pada dua makna inti dari framing, yaitu framing sebagai istilah untuk berita/wacana/ideologi/packages yang ada untuk khalayak untuk memahami sekelilingnya dan framing sebagai usaha atau operasi dari bagian-bagian konstituen yang bersama-sama berkontribusi pada frame tertentu (Hansen, 2015).

\section{Opini Publik (Public Opinion)}

Opini publik atau public opinion dapat diketahui ketika beberapa media massa seperti radio, surat kabar, dan para pembicara membicarakan mengenai suatu isu, kemudian mereka membentuk suatu anggapan yang membuat masyarakat berpikir demikian. Dalam bukunya yang berjudul "Opini Publik" (1997), Dra. Djoenaesih S. Sunarjo, SU menjelaskan pengertian opini publik menurut beberapa ahli adalah sebagai berikut:

Ferdinand mengemukakan bahwa terdapat tiga tahap opini publik dalam perkembangannya yaitu die luftartige, die flussige dan die feste, di mana opini publik die luftartige adalah opini publik yang dalam perkembangannya masing terombang-ambing mencari bentuk yang nyata, opini publik die flussige memiliki sifat-sifat seperti air, sudah memiliki bentuk yang nyata namun dapat dialirkan menurut saluran yang dikehendaki, sedangkan opini publik die festig merupakan opini publik yang sudah kuat dan tidak mudah berubah (Sunarjo, 1997).

Reckless dalam bukunya yang berjudul Social Psychology menyatakan bahwa suatu opini 
publik dalam penjelmaan dari pertimbangan seseorang tentang sesuatu hal, kejadian, atau pikiran yang telah diterima sebagai pikiran umum (Danusaputro, 1961). Opini publik dapat berubah-ubah, sedangkan perubahan itu sendiri dapat ditimbulkan dan disalurkan oleh seseorang atau suatu lembaga. Alat komunikasi yang menyalurkan opini publik adalah media massa (pers, radio, televisi dan film), namun yang paling utama adalah pers (Sunarjo, 1997).

Dalam tulisannya yang berjudul "Communication and Public Opinion, Berbard Berelson beliau menyatakan bahwa dengan pendapat publik diartikan people's response atau jawaban rakyat (persetujuan, ketidaksetujuan/penolakan atau sikap acuh tak acuh) terhadap isu atau hal yang bersifat politis dan sosial yang memerlukan perhatian umum, seperti hubungan internasional, kebijakan dalam negeri, pemilihan umum untuk calon-calon, dan hubungan antar kelompok etnik (Sastropoetro, 1990). Dengan berbagai penjelasan dari beberapa ahli tersebut maka dapat disimpulkan bahwa opini publik adalah merupakan persatuan pendapat (sintesa dari pendapat-pendapat yang banyak), sedikit banyak harus didukung oleh sejumlah orang, dalam opini publik orang menyatakan setuju atau tidak setuju terhadap gagasan atau terhadap suatu situasi maupun peristiwa, meskipun pembentukan opini publik biasanya melalui diskusi sosial, jadi seharusnya bersifat rasional, akan tetapi ikatan dalam opini publik tersebut sebagian besar masih terlihat dalam bentuk perasaan (emosional). Oleh karena itu opini publik merupakan persatuan dalam rangka perasaan atau emosi dan oleh sebab itu maka opini publik mudah berubah.

Perubahan opini ini dipengaruhi oleh seseorang atau suatu lembaga, terutama adalah media massa seperti pers, radio, televisi dan film. Opini publik biasanya didukung oleh sejumlah orang dengan ikatan emosional yang kuat, maka mungkin dilakukan dengan adanya suatu aksi misalkan demonstrasi atau unjuk rasa. Opini publik dapat dibentuk karena opini publik itu dibentuk, bukan berarti suatu fakta maka dari itu belum tentu benar. Opini publik selalu diawali dengan adanya diskusi sosial (Sunarjo, 1997).

Opini publik dapat dipengaruhi oleh hubungan masyarakat dan media politik. Selain itu, media massa menggunakan berbagai teknik penayangan untuk membuat pesan mereka tersampaikan dan mengubah pemikiran masyarakat. Sejak tahun 1950-an, televisi telah menjadi media utama untuk membentuk opini publik (Diggs-Brown, 2011). Pembentukan opini publik dimulai dengan agenda setting (pengaturan media) oleh media besar di seluruh dunia. Pengaturan agenda ini menentukan apa isu yang layak diberitakan, bagaimana dan kapan suatu berita dilaporkan.

\section{METODE PENELITIAN}

Pendekatan yang digunakan pada penelitian ini adalah dengan pendekatan kualitatif dan menggunakan metode penelitian analisis isi, yaitu dengan analisis framing dan priming mengenai isi pemberitaan yang diberitakan pada media massa dengan melakukan pendekatan tersebut, juga melakukan tanya jawab dengan informan untuk memperkuat analisis sudut pandang/agenda yang digunakan kedua media dalam membentuk suatu opini masyarakat. 
Pendekatan kualitatif bertujuan untuk membangun suatu proposisi atau menjelaskan arti/makna di balik suatu realita. Penelitian ini berupaya untuk memandang apa yang terjadi pada dunia tersebut dan melekatkan temuan-temuan yang diperoleh di dalamnya (Bungin, 2001).

Sugiyono (2012) mengatakan bahwa metode penelitian kualitatif adalah metode yang berlandaskan sifat post-positivism. Sifat penelitian ini adalah interpretatif, di mana penelitian interpretatif menurut Ghozali (2007) lebih berfokus kepada sifat objektif dari suatu komunitas sosial dan berusaha mempelajari kerangka berfikir objek yang sedang diteliti. Tujuan suatu penelitian dengan pendekatan interpretatif adalah untuk menganalisis realita sosial dan bagaimana sebuah realita sosial tersebut terbentuk. Kerangka framing Gamson \& Modigliani dipakai karena peneliti dapat menemukan wacana pokok yang muncul serta dapat membandingkan perangkat-perangkat framing dan pemahaman yang ada di dalam suatu berita. Peneliti dapat juga mengetahui bagaimana media membingkai suatu berita tentang terorisme dengan menggunakan model framing yang berfokus pada penggunaan kata, frasa dan gambar pada setiap berita sehingga peneliti dapat melihat stereotyping media terhadap terorisme.

Peneliti membagi proses pengumpulan data pada penelitian ini menjadi 2, yaitu level teks dan level konteks, sehingga peneliti dapat mencermati secara lebih detail tentang konstruksi media melalui perangkat framing Gamson dan Modigliani serta melakukan teknik wawancara dengan pihak-pihak terkait untuk mengumpulkan data pada level konteks. Pada level teks, peneliti mengumpulkan berita-berita yang dipublikasikan kedua media (Kompas.com dan VOAIslam.com) pada masing-masing portal beritanya, yaitu berita mengenai serangan teror di Paris yang terjadi pada tanggal 13 November 2015. Artikel yang digunakan pada penelitian ini merupakan pemberitaan dari media Kompas.com dan VOA-Islam.com yang dipublikasikan mulai dari tanggal 13 November 2015 hingga Januari 2016. Pemilihan tanggal ini didasarkan pada fokus pemberitaan di Indonesia, dimana pada tanggal tersebut intensitas kedua media dalam membahas mengenai peristiwa serangan Paris sangat tinggi. Pemilihan artikel juga didasarkan oleh kata kunci "Serangan Paris 2015", "Serangan teror Paris" dan "Terorisme di Paris" pada kolom pencarian.

Pada level konteks, peneliti menggunakan teknik pengumpulan data dengan berfokus kepada wawancara terstruktur dan wawancara semi terstruktur. Wawancara juga digunakan untuk mengetahui informasi terutama mengenai kebijakan dan agenda masing-masing media dalam memproduksi sebuah berita karena data-data tersebut tidak dapat diperoleh hanya dengan melalui analisis teks/framing.

Pada penelitian ini ada tiga narasumber yaitu (1) Ervan Hardoko, editor yang bertanggung jawab pada pemberitaan pada kolom berita Internasional khususnya mengenai serangan Paris 2015 pada media online Kompas.com. (2) Albertha Furqon, pemimpin redaksi yang bertanggung jawab pada pemberitaan mengenai serangan Paris 2015 pada media online VOAIslam.com. (3) AG Eka Wenats Wuryanta, dosen komunikasi dan akademisi media di Indonesia. 


\section{HASIL DAN PEMBAHASAN}

\section{Fleksibilitas Pemberitaan Isu Terorisme pada Media di Indonesia}

Terorisme dan media telah menjadi dua hal yang sangat berhubungan erat pada era kini, namun terorisme juga sudah ada jauh sebelum berkembangnya media atau teknologi informasi dan telekomunikasi. Tidak seperti sekarang, terorisme yang terjadi dahulu reaksinya tidak semasif sekarang yang apabila terjadi suatu aksi terorisme maka pemberitaanya akan bedampak ke seluruh dunia dalam waktu yang relative singkat. Hal ini tentunya merupakan efek dari perkembangan teknologi informasi dan komunikasi yang pesat. Berdasarkan hasil wawancara dengan AG Eka Wenats (2017) yang mengatakan bahwa saat ini suatu peristiwa bisa langsung diliput tanpa ada batas waktu seperti dulu misalnya koran atau televisi.

Pada era teknologi informasi ini media sangat berperan dalam penyebaran informasi terutama yang berkaitan dengan masalah umum atau isu-isu publik seperti isu sosial budaya, bisnis dan ekonomi, bencana alam, isu politik hingga terorisme. Tidak hanya pada media massa konvensional saja, media baru juga sangat berperan penting. Media baru seperti media berbasis internet atau online seperti media sosial dan media massa online juga akan lebih mudah menyebarkan isu-isu publik tersebut.

Menurut Martin (2006) dalam Tsauro (2016) media berperan dalam hal publikasi, penyebaran isu global dan menyajikan bentuk komunikasi massa baru bagi terorisme. Terorisme kemudian berujung memiliki basis media dengan segala proses penyebaran informasi dan pengiriman pesan pada pemirsa dan pembentukan iklim teror dilakukan oleh peran aktif media (Martin, 2006). Terorisme akan menjadi suatu hal yang sangat diperhatikan oleh masyarakat dunia apabila isu dan kasus teror yang terjadi disiarkan/dipublikasikan oleh media. Hal yang menguntungkan akan didapat pula oleh media yaitu dengan meningkatnya pendapatan dan rating pada suatu korporasi media apabila isu yang diangkatnya berpeluang untuk menarik minat dan perhatian pemirsanya. Sedangkan pada sisi teroris, mereka akan merasa aksi yang dilakukannya berhasil apabila mereka dapat menarik perhatian masyarakat dan menimbulkan suatu ketakutan, ketakutan tersebut pada awalnya dimunculkan dan disiarkan oleh media.

Isu mengenai terorisme pun menjadi suatu isu yang memiliki pengaruh besar pada media di Indonesia. Seperti data yang diperoleh peneliti, isu terorisme merupakan isu yang paling dibahas pada media massa sepanjang tahun 2015 menurut Indonesia Indicator (I2) yaitu mendominasi pemberitaan di 1.230 media online nasional dan media online internasional berbahasa Inggris (Susanti, 2015). Mulai dari pemberitaan terorisme di tanah air maupun terorisme di luar negeri seperti yang terjadi tiga tahun belakangan, mengenai menyebarnya teror-teror yang mengatasnamakan kelompok militant ISIS. Itulah sebabnya isu terorisme di Indonesia dapat menyebar dengan sangat cepat, media di Indonesia pun mengeluarkan reaksi yang masif sehingga isu terorisme dapat dengan mudahnya menutupi isu-isu lain yang dianggap tidak terlalu penting. 
Wenats (2017), pada wawancara yang dilakukan peneliti menjelaskan bahwa isu terorisme pada media masih kerap kali dikaitkan dengan suatu agama dan kelompok tertentu. Beliau juga sempat mengatakan bahwa Indonesia berada di sebuah wilayah di mana konteks religius masih sangat dominan dan terorisme sering kali di gambarkan kongruen dengan agama tertentu. Itu lah yang menyebabkan beberapa media tertentu di Indonesia dalam memberitakan tentang terorisme, walaupun masih secara halus, mencoba untuk merumuskan agenda yang ingin dibingkai dalam istilah terorisme, namun juga ada beberapa media yang dengan tegas langsung mengarah kepada kelompok-kelompok agama tertentu. Contohnya adalah ketika suatu media mengatakan bahwa terorisme dilandasi dengan alasan-alasan religius tertentu, bahkan mengatakan terorisme dioperasionalisasikan oleh kelompok fanatik dari agama tertentu, dan sebagainya. Pemberitaan terorisme di media mainstream di Indonesia pada umumnya langsung menunjuk kepada ISIS atau kelompok radikal terkait, namun pada waktu yang sama media juga memberitakan bahwa ISIS/ kelompok radikal tersebut bukan bagian dari agama tertentu. Sehingga dalam hal memberitakan tentang terorisme, kebanyakan media di Indonesia masih menggunakan berita penyeimbang sehingga terkesan halus dan tidak eksplisit.

\section{Sosiologi Media}

Sosiologi dan media menjadi kedua ilmu yang saling berpengaruh. Perkembangan teknologi informasi dan komunikasi yang cukup pesat membuat banyaknya media-media baru yang bermunculan. Media yang saat ini tidak bisa lepas dari kehidupan manusia adalah media berbasis internet. Di balik suatu media, media memiliki para pekerja media yang juga turut berpengaruh pada apa yang disajikan suatu media kepada khalayaknya. Individu yang tergabung di suatu korporasi media masa juga makhluk sosial yang saling berinteraksi dan berpartisipasi dengan suatu pola tertentu. Cara berbicara dan berpikir mereka pun berbeda dalam bahasa atau pola pikir kelompok di mana mereka berada. Rutinitas media inilah yang menunjuk pada pola-pola tertentu, bentuk dan praktik yang secara terus-menerus terjadi dalam aktivitas pekerja media (Shoemaker \& Reese, 1996).

Untuk memperkirakan produk media seperti apa yang dianggap menarik dan penting bagi audience, rutinitas media pun membentuk serangkaian asumsi yang dikenal dengan istilah "news values" atau nilai berita. Dalam hal ini Shoemaker dan Reese (1996) mengatakan bahwa news value berasal dari perhatian dan minat audience tertentu. Ketika suatu media dapat memberitakan semua yang terjadi dalam satu hari, maka yang sudah lewat menjadi tidak menarik lagi. Bahkan, terkadang berita yang dianggap menarik dan penting adalah sesuatu yang menyimpang dari rutinitas atau sesuatu yang secara langsung berpengaruh pada keseharian audience (Shoemaker \& Reese, 1996). Bad news atau berita tidak mengenakkan juga biasanya menjadi daya tarik masyarakat untuk mengkonsumsi informasi dari suatu media, dan tentu saja hal ini dapat mendongkrak keuntungan secara ekonomi bagi media tersebut.

Pada konteks ini media berlandaskan online telah menjadi kebutuhan masyarakat pada umumnya. Mengandalkan kecepatan/aktualitas dan juga keterbaruan berita, media online saat ini berkembang pesat hingga kedudukannnya nyaris menggantikan media cetak yang notabene kalah cepat dibandingkan dengan online. Pada hal ini para editor di media online diwajibkan 
untuk dapat terus mengeluarkan berita seiring dengan terjadinya suatu peristiwa, dapat menggunakan media yang telah tinggi kredibilitasnya atau media-media besar lain sebagai media pembanding. Hal ini dapat menunjang profit dan menarik audience apabila berita yang disajikan adalah berita yang buruk/bad news.

Latar belakang suatu korporasi media juga sangat mempengaruhi pembentukan suatu berita, dapat dilihat dari proses pendirian media, kepemilikan/pemodal media, visi-misi media, dan juga lebih condong ke arah mana kah suatu media berpedoman. Dapat berpedoman ke fakta peristiwa secara umum, ke arah moderat, persuasif, atau bahkan bersifat radikal. Visi dan misi media serta ideologi yang ada di dalamnya memaksa jurnalisnya untuk menciptakan dan mengkonstruksi suatu realita demi mencapai dan memenuhi visi dan misinya. Apa yang diberitakan media sesuai dengan visi dan misi nantinya akan membentuk persepsi dan opini yang serupa, sehingga dapat dikatakan juga media sebagai membentuk opini masyarakat.

\section{Tanggapan Pemberitaan Peristiwa Serangan Paris pada Media di Indonesia}

Opini suatu masyarakat dapat dipengaruhi oleh apa yang mereka konsumsi pada media, apa dan siapa yang ada sekeliling mereka. Seperti halnya pada saat terjadi serangan di Paris, banyak masyarakat di Indonesia yang menilai peristiwa tersebut adalah aksi teror yang dilakukan suatu kelompok militan dan harus diwaspadai. Media di Indonesia pun memiliki pendapatnya masing-masing terhadap berbagai pemberitaan peristiwa ini. Melalui hasil wawancara, Eka Wenats (2017) berpendapat bahwa masyarakat juga perlu memahami bahwa media itu juga mempunyai pilihan-pilihan ideologi tertentu sehingga terkadang pilihan ideologi tertentu itu menjadi pilihan yang mau tidak mau harus kontra dengan kegiatan teror itu yaitu tentang counter-terror. Counter-terror tersebut dapat dengan mengatakan melalui media bahwa aksi itu tidak menimbulkan efek apa-apa kepada masyarakat, contohnya seperti di Indonesia.

Media mainstream di Indonesia secara umum ingin menggambarkan bahwa terorisme adalah suatu tindak kejahatan sosial murni, meskipun terkadang masih diberitakan dengan menggunakan simbol-simbol dari kelompok dari agama tertentu. Hal ini menurut Furqon (2017) yang merupakan pemimpin redaksi media Muslim VOA-Islam.com berpendapat bahwa media di Indonesia tidak adil karena hampir selalu menyebut kejahatan yang dilakukan oleh umat Muslim adalah teror, sedangkan aksi kejahatan kemanusiaan lain yang tidak dilakukan oleh Muslim tidak dikatakan oleh media sebagai aksi teror. Selain itu, media mainstream jarang meliput apa hal yang menyebabkan terjadinya suatu aksi terorisme. Beliau berpendapat bahwa sesuatu dikatakan aksi teror apablia menimulkan suatu keresahan dan ketakutan, tidak hanya kejahatan yang dilakukan umat Muslim, namun pada kenyataannya media tidak memberitakan hal yang sama apabila kejahatan teror tersebut dilakukan oleh umat beragama lain.

Ervan Hardoko (2017) selaku editor desk internasional Kompas.com berpendapat bahwa pemberitaan di Indonesia cenderung dibuat untuk membenci terorisme, bukan membenci agama tertentu. Di samping itu beliau mengatakan pemberitaan yang mendukung Muslim di Indonesia juga masih ada, sehingga tidak bisa disebut bahwa media di Indonesia menciptakan bingkai untuk membenci umat beragama tertentu. Kompas.com berpendapat bahwa mereka 
yang juga termasuk media mainstream hanya berpihak kepada korban sipil seperti pemberitaan lainnya, tidak berpihak kepada media barat sepenuhnya karena juga masih memberitakan sisi lain umat Muslim yang sering kali hanya dijadikan bahan tuduhan atas suatu aksi terorisme. Hal tersebut dapat berupa pemberitaan mengenai seruan petinggi umat Muslim yang tidak mengakui tindakan terorisme adalah bagian dari Islam.

\section{Priming: Pemberitaan pada Media Kompas.com dan VOA-Islam.com}

Berita mengenai Serangan Paris di Kompas.com dan VOA-Islam.com dapat dilihat menggunakan kata kunci seperti "Serangan Paris" "Paris attack" "Serangan Teror Paris November 2015" dan "ISIS teror Paris". Dapat dilihat melalui grafik bahwa berita yang dikeluarkan oleh kedua media online kuantitasnya tidaklah sama, Kompas.com lebih banyak memberitakan mengenai serangan Paris pada tanggal 14 November sebanyak 38 berita sedangkan VOA-Islam.com bahkan tidak mencapai 10 berita. Angka pada grafik menunjukan kuantitas berita kian menurun seiring dengan berjalannya waktu, sehingga dapat disimpulkan bahwa kedua media melakukan priming (hanya menyajikan isu terserbut saat sedang hangathangatnya diperbincangkan oleh masyarakat dan berbagai media di dunia) dan menutupi isu lain yang dianggap masyarakat tidak terlalu penting.

Hal ini juga diakui oleh pihak editor dan pimpinan redaksi dari Kompas.com dan VOAIslam.com melalui wawancara yang dilakukan. Editor desk Internasional Kompas.com, Ervan Hardoko (2017) mengaku memberitakan peristiwa tersebut hanya berdasarkan fakta 5W1H dan akan tetap memberitakannya selama berita itu ada bahannya baik mengenai peristiwa atau halhal disekitarnya. Basis online adalah alasan dibalik terus dibuatnya berita peristiwa tersebut karena media online sangat berpacu pada kecepatan berita dan banyaknya berita sehingga dapat menutupi isu lain yang tidak penting.

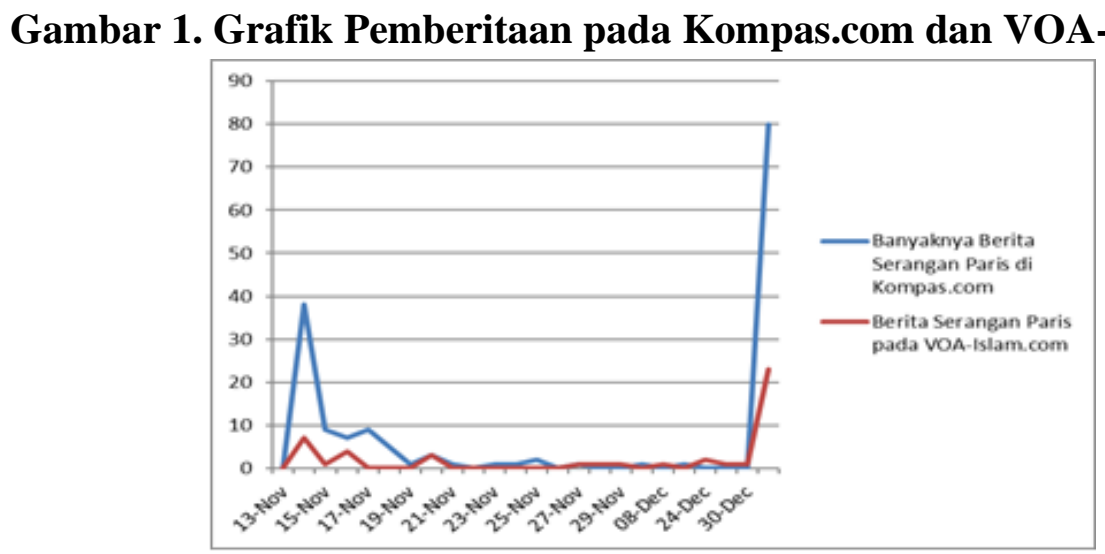

Sumber: Data Olahan Peneliti, 2017

\section{Agenda Setting Media}

VOA-Islam menilai bahwa media mereka adalah media perlawanan, sehingga pada peristiwa ini mereka lebih memberitakan kepada mengapa Paris di serang, dan juga berita-berita dari sudut pandang ISIS yang tidak semata hanya melakukan serangan tersebut tanpa alasan. Berbeda dengan media pada umumnya yang tidak menyiarkan alasan mengapa ISIS menyerang 
Paris, VOA-Islam mencoba memberikan informasi kepada masyarakat bahwa serangan Paris adalah suatu reaksi dari dukungan Perancis untuk menyerang Suriah dan Irak. Media ini juga mengaku mengutip dari beberapa media asing barat seperti media di Indonesia pada umumnya, namun mereka juga mengutip beberapa dari media timur tengah seperti Al-Jazeera, Al-Arabia karena dianggap memberitakan peristiwa tersebut dengan cara pandang yang berbeda dengan media asing barat, media-media timur tengah ini diambil sebagai media pembanding dari sisi lain selain sisi barat.

Pada sisi lain, editor Kompas.com mengatakan bahwa mereka tidak melakukan agenda setting maupun framing pada pemberitaan mereka, melainkan hanya mengandalkan fakta. Dalam hal pengutipan beliau juga mengakui bahwa Kompas.com bekerja sama dengan media asing BBC, dan kerap mengambil berita dari media-media asing di barat karena mereka tidak memiliki kontributor resmi dari kantor, sehingga hanya dapat mengandalkan berita-berita dari media asing yang notabene berada di sana pada saat serangan terjadi. Mereka juga mengutip beberapa berita dari media timur tengah sebagai pelengkap informasi karena saat itu ada beberapa informasi yang tidak ada di media barat, namun diberitakan di media timur tengah. Media timur tengah pada hal ini hanya sebagai pelengkap informasi.

Sejauh ini Kompas.com mengaku tidak melakukan menggiringan opini/persepsi atau pembingkaian berita untuk membenci kelompok beragama tertentu, namun hanya agar masyarakat membenci aksi terorisme. Ervan (2017) menilai apa yang terjadi di sana adalah hal yang kompleks, jadi tidak dapat dikatakan semudah itu dengan menohokkan pertanyaan kepada media apakah mereka melakukan framing atau tidak, sedangkan pimpinan redaksi VOA-Islam.com menilai adalah bohong apabila suatu media tidak melakukan framing, karena dibalik suatu media pasti ada kepentingan dan ideologi tertentu (Furqon, 2017).

VOA-Islam yang target audiencenya adalah masyarakat umum terutama Muslim, dalam memberitakan terorisme biasanya dianggap terlalu menunjukkan sisi perlawanan sehingga sering kali diblokir oleh pihak berwenang. Padahal, pimpinan redaksi mengatakan kebanyakan berita yang diblokir adalah berita biasa dan tidak bermasalah, hanya dikarenakan pihak-pihak yang menilai media Muslim adalah media yang radikal, padahal media Muslim hanya ingin menunjukkan kepada masyarakat sisi lain yang tidak diberitakan oleh media-media pada umumnya. Berbeda halnya dengan Kompas.com yang dikatakan edior Kompas.com sendiri kerap dianggap pihak tertentu sebagai media yang membenci Muslim, hingga sempat ada suatu forum pembenci Kompas karena pemberitaannya yang menyudutkan umat Muslim, namun mereka menganggap pemberitaannya hanyalah berdasarkan fakta dan tidak ada pembingkaian yang berusaha dibentuk. Dengan pengakuan kedua media tersebut, penulis akan melakukan analisis mendalam menggunakan analisis framing untuk membuktikan keabsahan informasi yang telah di dapat melalui wawancara dengan pihak redaksi.

\section{Analisis Framing Media Kompas.com dan VOA-Islam.com}

Pemuatan berita suatu media pada dasarnya telah memiliki syarat-syarat suatu berita yaitu, faktual, akurat dan seimbang (Rusadi, 2015). Rusadi (2015) pada bukunya juga mengatakan 
bahwa untuk dapat mengetahui representasi ideologi suatu korporasi media, walaupun ideologi suatu media sudah dapat dilihat melalui visi dan misinya, atau dengan hasil wawancara oleh pimpinan media yang menjelaskan ke mana arah suatu media dan apa pedomannya, suatu penelitian mengenai ideologi media tetap harus disertai dengan rumusan ideologi sebagai kerangka analisis.

Pada penelitian ini peneliti menggunakan analisis framing model Gamson dan Modigliani untuk memdalami analisis, yang meiliputi perangkat-perangkat framing seperti metaphors, catchphrases, depiction, exemplar dan visual image, dengan perangkat reasoning yang meliputi root, consequency dan apply to principle. Pada bagian analisis framing, artikel yang akan dianalisis beritanya adalah artikel dengan tema "Serangan teror di Paris". Dari analisis framing yang dilakukan, peneliti menemukan bingkai besar yang dibentuk oleh Kompas.com dan VOA-Islam.com yang secara umum mengandung masing-masing 2 ide utama yaitu pada Kompas.com yaitu kecaman terhadap serangan teror Paris (mewaspadai dan melawan ISIS) dan situasi dan reaksi masyarakat dunia pasca serangan Paris November 2015. Pada VOAIslam.com yaitu reaksi dunia pasca-serangan teror di Paris (termasuk ISIS) dan keberpihakan masyarakat dunia terhadap Perancis pasca-serangan teror.

Peneliti memilih 6 artikel yang paling representatif untuk dianalisis menggunakan perangkat framing yang dikemukakan oleh Gamson dan Modigliani (1989, p.3). Tiga artikel pertama dipilih dari artikel dengan frame "Situasi dan reaksi di berbagai negara di dunia pasca serangan Paris November 2015" dan 3 artikel selanjutnya diambil dari frame "Kecaman terhadap serangan teror Paris (mewaspadai dan melawan terorisme)". Kedua frame besar dipilih karena dianggap dominan dalam pemberitaan yang judulnya akan dijabarkan lebih lanjut. Data disajikan dalam dua tabel yang dibagi atas dua frame besar tersebut, dan berikut adalah tabel pembagian judul berdasarkan dua frame yang peneliti lakukan. Pada frame pertama yaitu "Kecaman terhadap serangan teror Paris (mewaspadai dan melawan terorisme)", Kompas.com membentuk suatu gagasan mengenai tokoh besar Negara-negara di berbagai belahan dunia yang mengecam serangan teror tersebut dan dalam frame ini, Kompas.com banyak menyorot dan memasukkan gambar-gambar mengenai peristiwa terkait, dari gambar kekisruhan saat serangan terjadi, hingga saat tokoh-tokoh penting dunia bereaksi akan peristiwa teror. Frame pertama ini juga mewakili suatu kecaman terhadap bentuk terorisme dan agar masyarakat tetap mewaspadai dan melawan terorisme, karena terorisme dianggap masih menghantui.

Pada frame besar yang kedua yaitu "Situasi dan reaksi di berbagai negara di dunia pasca serangan Paris November 2015", Kompas.com memberitakan mengenai penggambaran yang cukup lengkap mengenai peristiwa Serangan Paris pada tanggal 13 November waktu setempat. Tidak hanya di Perancis saja, melainkan keterkaitan peristiwa tersebut dengan beberapa Negara lain seperti Indonesia yang turut melakukan pengamanan ketat dan menyerukan travel warning kepada warga Negara yang hendak berkunjung ke Perancis, pengamanan ketat di beberapa wilayah terkait dengan Perancis, hingga pengaruhnya kepada ekonomi dan politik dunia. Frame ini lebih menekankan pada situasi setelah terjadinya serangan teror. 
Setelah itu dilakukan analisis framing dengan model Gamson \& Modigliani dengan 3 berita representatif dari frame besar dari berita-beita Kompas.com. Judul berita tersebut diantaranya kecaman terhadap serangan teror paris (mewaspadai dan melawan terorisme) (1) Presiden Iran: Serangan Paris adalah tindakan kriminal terhadap kemanusiaan, (2) Obama: Serangan Paris adalah serangan terhadap kemanusiaan, dan (3) Tragedi Paris jadi bukti terorisme terus mengancam. Selanjutnya judul berita situasi dan reaksi di berbagai negara di dunia pasca serangan Paris November 2015 (1) Usai Serangan di Paris, New York Kerahkan Ribuan Polisi, (2) Serangan Paris Timbulkan Kecemasan Baru Terhadap Ekonomi Dunia dan (3) Paris Tutup Fasilitas Publik Pasca-Serangan Berdarah.

Analisis framing pada ke tiga berita dari Kompas.com ini menunjukkan adanya kesamaan secara garis besar pada gambaran umum situasi dan reaksi di berbagai dunia pasca-serangan Paris November 2015. Hal ini dapat dilihat dari judul masing-masing berita yang merupakan aksi setelah masyarakat mengetahui teroris telah memporakporandakan kota Paris. Reaksinya merupakan efek dari kekhawatiran yang ada. Tidak hanya di kota Paris saja, bahkan hingga ke New York dan ekonomi dunia.

Sama halnya seperti analisis bingkai pada Kompas.com, peneliti memilih 6 berita yang paling representatif untuk dianalisis menggunakan perangkat framing yang dikemukakan oleh Gamson dan Modigliani (1989, p.3). Tiga artikel pertama dipilih dari artikel dengan frame "Reaksi dunia pasca-serangan teror di Paris (termasuk ISIS)" dan 3 artikel selanjutnya diambil dari frame "Keberpihakan orang asing terhadap Prancis". Frame besar kedua VOA-Islam.com yaitu "Keberpihakan masyarakat dunia terhadap warga Perancis pasca-serangan teror", beberapa beritanya menjelaskan bahwa masyarakat dunia lebih peduli jika masyarakat asing yang terkena musibah seperti teror bom seperti ini. Beberapa berita juga menekankan betapa Negara asing terutama sekutu Perancis, hingga Indonesia turut simpati dan mendukung gerakan serangan balik yang dilakukan Perancis terhadap Suriah pasca-teror Paris.

Setelah itu dilakukan analisis framing dengan model Gamson \& Modigliani dengan 3 berita representative dari frame besar dari berita-beita Kompas.com. Judul berita tersebut diantaranya reaksi dunia pasca-serangan Paris (termasuk ISIS) yaitu (1) Belgia tingkatkan pengamanan di perbatasan setelah serangan Paris, (2) IS janji menyerang Perancis lagi, bila tidak hentikan serangan di Suriah, dan (3) Malaysia kerahkan 2000 tentara di ibukota untuk jaga Obama dari 'serangan teroris'. Selanjutnya judul berita keberpihakan masyarakat dunia terhadap warga Perancis pasca-serangan teror yaitu (1) Capres AS Donald Trump Serukan Warga Prancis di Izinkan Bawa Senjata, (2) Panglima TNI Jendral Gatot Nurmantya dan Jendral Badirodin Haiti Siap Hadapi ISIS, (3) Hebat! Presiden Jokowi sama dengan Hollande dan Barack Obama. Analisis framing yang dilakukan terhadap ketiga berita menggambarkan bahwa VOA-Islam mencoba membentuk suatu berita yang berbeda dengan media massa lainnya, yaitu dengan suatu pertimbangan bahwa Negara-negara di dunia berpihak kepada Perancis, bahkan Negara Indonesia sendiri. 
Analisis yang dilakukan menunjukkan beberapa hal yang berbeda. Pada pemberitaan Kompas.com mengenai serangan Paris, diakui oleh editor bahwa Kompas semata-mata hanya mengandalkan informasi yang ada, dan informasi yang ada tersebut diolah berdasakan fakta. Berita yang dikeluarkan berdasarkan ketersediaan informasi yang ada baik dari media asing barat maupun Timur Tengah, karena media Timur Tengah juga digunakan sebagai pelengkap informasi dan juga pembanding. Informasi pelengkap maksudnya adalah untuk mendapatkan informasi yang terkadang tidak didapatkan dari media asing barat pada umumnya. Pemberitaan juga tidak hanya mengenai serangan Paris saja, tapi juga berupa ulasan-ulasan pelaku, siapakah dibalik serangan tersebut, apa reaksi dunia tentang serangan tersebut termasuk reaksi di Indonesia sendiri (Hardoko, 2017).

Di samping pengakuan tersebut peneliti yang juga melakukan analisis framing pada 6 berita yang dianggap paling representatif menganggap Kompas.com juga masih melakukan beberapa penekanan pada kata-kata seperti "mengutuk serangan berdarah," "Mengecam," dan "melawan terorisme," yang mengarah kepada pembentukan suatu presepsi bahwa dunia harus melawan terorisme, namun pada kasus ini terorisme yang terjadi telah diklaim oleh ISIS yang notabene mengakui bagian dari umat beragama Muslim. Beberapa pelaku teror yang namanya khas dengan nama orang Timur Tengah/Arab juga kerap dijadikan headline oleh Kompas yang menandakan pelaku serangan teror adalah Muslim.

Kompas juga melakukan suatu pemberitaan mengenai dunia yang pada saat itu terlihat panik dengan melakukan pengamanan ekstra pasca serangan, hal ini menunjukkan bahwa seolah dunia khawatir akan serangan teror susulan yang memungkinkan untuk terjadi. Berbeda dengan apa yang dikatakan editor Kompas.com yang mengatakan bahwa mereka tidak melakukan framing, namun beberapa beritanya mencoba membentuk suatu persepsi untuk membenci terorisme, pada framing yang dilakukan, Kompas.com juga membentuk suatu ketakutan terhadap terorisme.

Berbeda dengan media-media pada umumnya yang memiliki viewers lebih banyak, dibandingkan VOA-Islam.com yang audience-nya lebih tersegmentasi, pemimpin redaksi VOA-Islam.com, Albertha Furqon, mengakui bahwa media Islam di Indonesia adalah sebagai bentuk perlawanan dari media pada umumnya yang dinilai beliau tidak merepresentasikan apa dan bagaimana sebenarnya peristiwa yang terjadi. VOA-Islam pada pemberitaan mengenai serangan Paris mengakui memberitakan sisi lain yang menjelaskan bahwa serangan Paris adalah suatu reaksi dari dukungan yang dilakukan oleh Perancis pada saat menyerang Suriah dan Irak sebelumnya. Pada analisis framing yang dilakukan, terlihat bahwa VOA-Islam menunjukkan keberpihakan media asing dan dunia pada Perancis, namun dunia tidak terlalu berpihak kepada negara-negara Timur Tengah yang pada saat-saat tertentu juga di serang oleh barat, membunuh masyarakat sipil yang tidak bersalah namun tidak diberitakan seperti yang terjadi di Perancis. Pada analisis framing yang telah dilakukan, terlihat pula headine berita yang sama dengan media mainstream, namun hanya sebagai data berupa kronologi kejadian (Immanuel \& Pannindriya, 2020). 
Pada penjelasan mengenai pelaku serangan dan lainnya, VOA-Islam tidak berfokus pada korban penyerangan, namun berfokus pada penyerang yang melakukan serangan tersebut dan apa aksi selanjutnya yang akan mereka lakukan terhadap Perancis. Analisis framing menunjukkan benar adanya yang dikatakan oleh pemimpin redaksi VOA-Islam yaitu media ini mencoba memberitakan sisi lain yang tidak diberitakan oleh media-media mainstream lainnya sehingga media kerap dikatakan sebagai media radikal pendukung aksi terorisme dan sering menerima sanksi blokir oleh KEMKOMINFO.

\section{SIMPULAN}

Setelah dilakukan analisis data, dengan melakukan wawancara terhadap pihak terkait dalam penelitian ini dan dengan analisis framing yang dilakukan, kemudian data diolah kembali, maka simpulannya adalah bahwa kedua media memberitakan dengan sudut pandang dan cara yang berbeda dalam peristiwa serangan Paris November 2015. Melalui serangkaian hasil wawancara dan analisis, penelitian ini menghasilkan suatu pembuktian bahwa setiap media akan memberitakan suatu peristiwa menurut ideologi dan ciri khas masing-masing tergantung dari editor/redaktur media tersebut, termasuk dalam pemilihan referensi dan media asing sebagai media pembanding.

Ideologi redaktur pada hal ini adalah yang sangat berpengaruh dalam pembuatan suatu berita, karena di dalam media itu sendiri tidak memiiki kontributor resmi yang mereka terjunkan ke lokasi di mana peristiwa terjadi, maka tiap editor hanya bergantung kepada media-media asing yang notabene lebih dahulu menerbitkan berita tersebut karena secara langsung dapat meliput dan melihat peristiwa yang terjadi. Media Kompas.com, setelah dianalisis melalui hasi wawancara lebih bergantung kepada fakta dan hanya memberitakan fakta berupa kronologi pada peristiwa tersebut, namun setelah dilakukan analisis framing pada ke 6 berita yang paling representatif, Kompas.com juga melakukan penekanan-penekanan pada beberapa istilah yang mengarahkan suatu pemikiran bahwa terorisme adalah sesuatu tindak kriminal yang dibenci dunia dan harus dilawan bersama, entah apa motivasi dan siapa dibelakang tindak terorisme tersebut.

Pada sisi lain, media VOA-Islam, setelah dianalisis menggunakan hasil wawancara, lebih memberitakan kepada umat Muslim yang pada peristiwa ini diduga menjadi pelaku serangan teror, dan menganggap terorisme tidak perlu ditakuti seperti itu, karena pihak Perancis pun melakukan tindak serangan yang sama kepada umat Muslim di Suriah. Setelah dianalisis menggunakan analisis framing dan mengidentifikasi beberapa berita yang paling representatif, VOA-Islam.com membuktikan bahwa serangan teror berlandaskan suatu alasan tidak sematamata hanya menyerang orang-orang tidak bersalah, dan menganggap bahwa dunia terlalu berpihak kepada masyarakat non-Muslim, termasuk petinggi Negara Indonesia.

Saran akademis dapat digunakan untuk penelitian selanjutnya yang ingin meneruskan penelitian ini maupun mengusung tema serupa. Di sini peneliti menyarankan untuk siapapun yang akan melanjutkan atau mengadakan tema penelitian sama agar dapat meneliti dalam 
bagaimana suatu/kedua media memberitakan suatu isu, dapat ditinjau dari sudut pandang dan frame yang digunakan oleh media tersebut dan dengan menanyakan langsung kepada pembuat berita tentang bagaimana mereka memberitakan suatu peristiwa yang diangkat

Saran praktis ini ditujukan kepada media di Indonesia, diharapkan oleh penulis untuk dapat memberitakan suatu peristiwa secara aktual dan jujur tanpa mempengaruhi pihak-pihak termasuk masyarakat umum dalam konteks negatif. Kedua media dapat saling mengevaluasi pemberitaan mereka selama ini apakah telah memenuhi kebenaran dan kode etik secara fakta dan tanpa pengaruh dari media-media yang mencoba membentuk suatu agenda atau opini tertentu.

\section{DAFTAR PUSTAKA}

Danusaputro, M. (1961). Bahan Kuliah Tertulis, Pengantar Ilmu Jurnalistik \& Publistik. Bandung: Universitas Negeri Padjajaran, Bandung.

Diggs-Brown, B. (2011). Strategic Public Relations: Audience Focused Practice.

Djoenaesih S. Sunarjo, S. (1997). Opini Publik. Yogyakarta: Liberty Offset Yogyakarta.

Gamson, W., \& Modigliani, A. (1989). Media Discourse and Public Opinion on Nuclear Power: A Constructionist Approach. American Journal of Sociology, 1-37.

Immanuel, G., \& Pannindriya, S. T. (2020). Dampak Globalisasi Terhadap Gaya Berpakaian Generasi Z Bali. COMMENTATE: Journal of Communication Management, 1(2), 162175.

Hansen, A. (2015). Communication, Media And The Social Construction of The Environment. In Hansen, Anders \& Cox, Robert, The Routlegde Handbook of Environment and Communication. Oxon: Routledge.

Martin, G. (2006). The Information Battleground: Terrorist Violence and The Role of the Media. In Understanding Terrorism 2nd Edition. London: SAGE Publications.

Nugroho, D. P. (2020). Komunikasi dan Analisis Media dalam Evakuasi Mahasiswa WNI dari Thailand Saat Pandemi COVID19. COMMENTATE: Journal of Communication Management, 1(1), 1-19.

Rusadi, D. (2015). Kajian Media: Isu Ideologis Dalam Perspektif, Teori dan Metode. Jakarta: PT Rajagrafindo Persada.

Sastropoetro, S. (1990). Pendapat Publik, Pendapat Umum dan Pendapat Khalayak dalam Komunikasi Sosial. Bandung, Indonesia: Remaja Rosdakarya.

Susanti, R. (2015). Survei: Terorisme Internasional, Kejahatan Paling Disorot Media Online Sepanjang 2015. Retrieved from internasional.kompas.com: http://nasional.kompas.com/read/2015/12/27/09102341/Survei.Terorisme.Internasional. Kejahatan.Paling.Disorot.Media.Online.Sepanjang.2015

Tsauro, M. A. (2016). Mass Media and Terrorism: A Case Study of Paris Terrorist Attack 13/11 and Global Breaking News. 